\author{
Andrzej CIEŚLIK ${ }^{1}$ \\ Andrzej PAZUR ${ }^{2}$ \\ Andrzej SZELMANOWSKI ${ }^{3}$
}

\title{
METODY KONWERSJI DANYCH NAWIGACYJNYCH W UKLADACH ODNIESIENIA STOSOWANYCH W ZINTEGROWANYCH SYSTEMACH AWIONICZNYCH
}

\begin{abstract}
W artykule przedstawiono wyniki prac realizowanych w Instytucie Technicznym Wojsk Lotniczych w zakresie możliwości komputerowej konwersji danych nawigacyjnych w układach odniesienia stosowanych w zintegrowanych systemach awionicznych. Na przykładzie systemu awionicznego śmigłowca W-3PL Głuszec przedstawiono możliwości przetwarzania danych pilotażowo-nawigacyjnych i celowniczych podczas realizacji misji obserwacyjnych (przy wykorzystaniu głowicy TOPLITE) oraz wykorzystania systemu uzbrojenia z nahełmowym systemem celowniczym NSC-1 Orion. Dla ilustracji realizowanych w nim operacji przetwarzania informacji pilotażowo-nawigacyjnej i obserwacyjno-celowniczej, omówiono metody konwersji danych nawigacyjnych w trybie CCIP oraz trybie CCRP.
\end{abstract}

Słowa kluczowe: lotnicze systemy nawigacyjne, transformacja danych

\section{Wprowadzenie}

Standardowym wyposażeniem współczesnych statków powietrznych są zintegrowane systemy awioniczne, elektronicznie pozyskujące, przetwarzające i dystrybuujące informację pilotażowo-nawigacyjną z wewnętrznych (pokładowych) i zewnętrznych źródeł danych. Zastosowanie zintegrowanych systemów awionicznych w wojskowych statkach powietrznych pozwoliło na zwiększenie ich możliwości bojowych oraz rozszerzenie rodzajów i zakresu realizowanych przez nie misji z wykorzystaniem wymaganych parametrów lotu [1, 2, 6, 9].

\footnotetext{
1 Autor do korespondencji/corresponding author: Andrzej Cieślik, Instytut Techniczny Wojsk Lotniczych, 01-494 Warszawa, ul. Księcia Bolesława 6, tel.: 22 261-851-405,

e-mail: andrzej.cieslik@itwl.pl

2 Andrzej Pazur, Instytut Techniczny Wojsk Lotniczych, e-mail: andrzej.pazur@itwl.pl

${ }^{3}$ Andrzej Szelmanowski, Instytut Techniczny Wojsk Lotniczych, e-mail: andrzej.szelmanowski@itwl.pl
} 
Wykonane analizy m.in. [3, 8] wykazały, że aby informacja pilotażowonawigacyjna oraz dane obserwacyjno-celownicze mogły być efektywnie wykorzystane, muszą być określane $\mathrm{w}$ tych samych układach współrzędnych lub konwertowane (przetwarzane) pomiędzy układami współrzędnych związanymi z wybranymi elementami ruchomymi statku powietrznego (m.in. układem głowicy obserwacyjno-celowniczej, układem ruchomego stanowiska strzeleckiego, układem koordynatorów głowic kierowanych pocisków rakietowych).

Wprowadzenie na pokład zintegrowanych urządzeń do precyzyjnego określania bieżącej orientacji przestrzennej oraz pozycji nawigacyjnej statku powietrznego $[5,7]$ (m.in. systemy nawigacji inercjalnej i systemy pozycjonowania satelitarnego) umożliwiło określanie w systemach uzbrojenia informacji o bieżącym punkcie celowania pocisku lub upadku bomby (tryb CCIP) oraz informacji o zapasie czasu dolotu do punktu, w którym należy odpalić pocisk lub zrzucić bombę (w trybie ręcznym), aby trafiła w wybrany cel (tryb CCRP).

\section{Zintegrowane systemy awioniczne - rodzaje i etapy rozwoju}

Zintegrowane systemy awioniczne można podzielić ze względu na sposób połączeń wykonanych pomiędzy blokami elektronicznymi (rys. 1) i wyróżnić następujące ich rodzaje [3]:

- systemy z analogowym przesyłaniem sygnałów,

- systemy z cyfrowym przesyłaniem sygnałów,

- systemy zintegrowane cyfrowo,

- systemy zintegrowane modułowo.

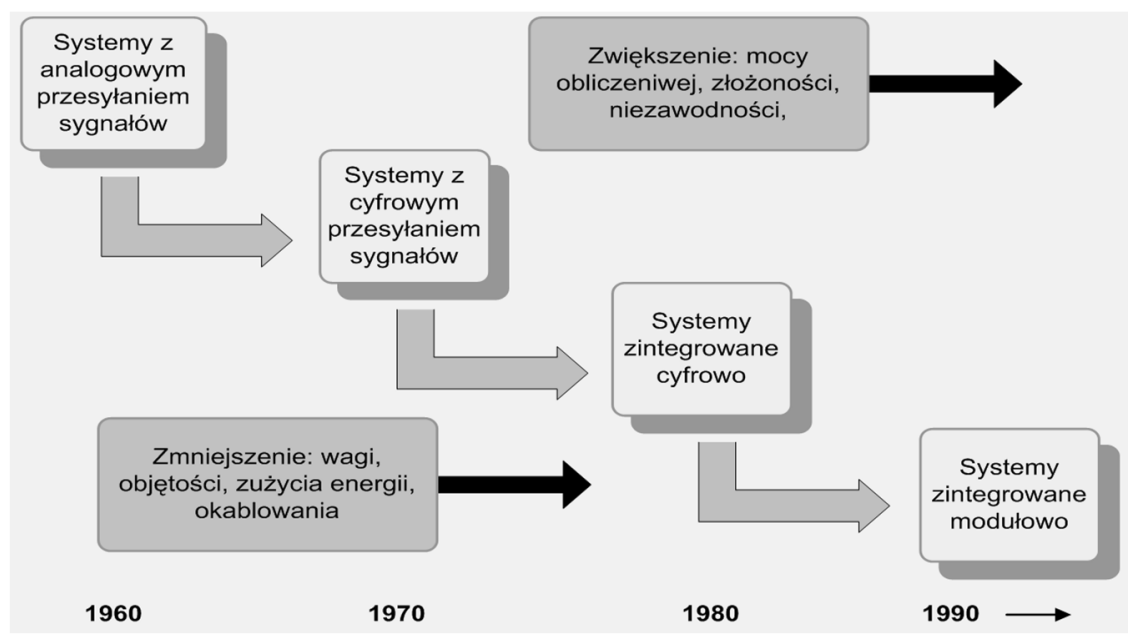

Rys. 1. Rodzaje zintegrowanych systemów awionicznych z uwagi na sposób połączenia

Fig. 1. Types of integrated avionic systems due to the connection method 
Powstanie zintegrowanych systemów awionicznych było naturalnym następstwem przenikania się wielu podsystemów statku powietrznego. Integracja systemu awionicznego polega na elektronicznym (komputerowym) zespoleniu wielu podsystemów w jeden system, który spełnia wymagania stawiane danemu typowi statku powietrznego. Powstały w wyniku takiego zespolenia system nazywa się zintegrowanym systemem awionicznym [3, 6]. Historia integracji systemów awionicznych sięga lat 50. ubiegłego wieku, kiedy to zapoczątkowano prace nad zwiększeniem efektywności lotu i wykonania zadania przez załogę statku powietrznego. Efektem tym prac było pojawienie się w latach 60 . ubiegłego wieku pierwszych samolotów wyposażonych w zintegrowane systemy awioniczne. Kolejnym etapem rozwoju było powstanie monitorów wielofunkcyjnych MFD (Multi Function Display) oraz wskaźników przeziernych HUD (Head-Up Display) i systemów nahełmowych HMD (Helmet Mounted Display), umożliwiających zobrazowanie informacji z różnych podsystemów statku powietrznego na jednym wyświetlaczu.

Systemy zintegrowane cyfrowo pojawiły się wraz z rozwojem pokładowych cyfrowych standardów transmisji danych jak wojskowy MIL-1553B, czy cywilny ARINC-429 [4, 6]. Standardy te doprowadziły do unifikacji urządzeń pokładowych, a ich cechą charakterystyczną jest centralna magistrala danych, do której podłączone są urządzenia elektroniczne wchodzące w skład systemu zintegrowanego jak: komputer misji, monitory wielofunkcyjne, system nawigacji inercjalnej, centrala danych aerodynamicznych itd. Wprowadzenie centralnej magistrali danych doprowadziło do zmniejszenia liczby urządzeń transmisji danych i ilości okablowania montowanego na pokładzie statku powietrznego.

Systemy zintegrowane modułowo pojawiły się w następstwie wykorzystania do produkcji systemów zintegrowanych powszechnie stosowanych modułów elektronicznych dopuszczonych do zastosowań na pokładach statków powietrznych. Cechą charakterystyczną tych systemów jest zwiększenie szybkości transmisji informacji pomiędzy modułami elektronicznymi, wprowadzenie procesorów sygnałowych do przetwarzania danych oraz wprowadzenie tzw. oprogramowania wieloplatformowego $[3,6]$.

\section{Wizualizacja parametrów lotu w systemach zintegrowanych}

Zasadnicze zmiany w sposobie wizualizacji parametrów nawigacyjnopilotażowych pojawiły się wraz z wprowadzeniem na pokład wskaźników przeziernych HUD oraz wyświetlaczy nahełmowych HMD. Umożliwiają one prezentację parametrów lotu „na horyzoncie”, co daje możliwość prowadzenia nawigacji bez konieczności przenoszenia wzroku na przyrządy nawigacyjne (rys. 2). W wielu fazach lotu statku powietrznego istnieje konieczność zobrazowania na wskaźnikach przeziernych punktów orientacji przestrzennej, które mają swoje odzwierciedlenie w rzeczywistym terenie. Oznacza to, że w polu wi- 
doczności wskaźnika przeziernego pilot ma zobrazowany punkt, którego współrzędne pokrywają się z pozycją symbolu na wskaźniku przeziernym [6].
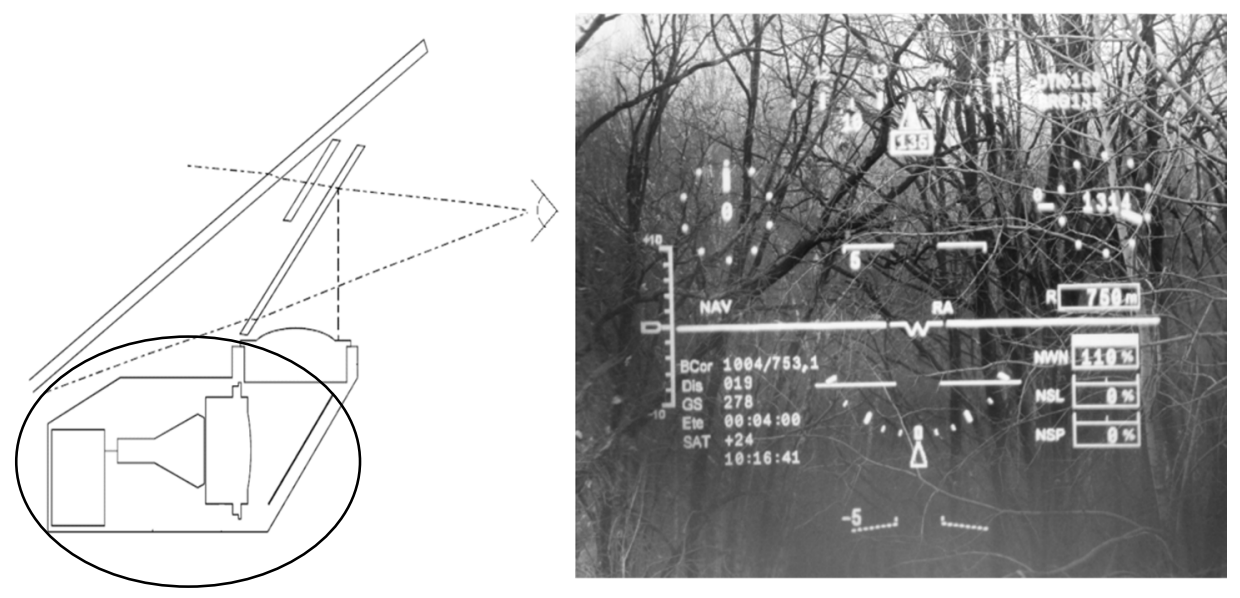

Rys. 2. Budowa wskaźnika przeziernego (po lewej) i sposób prezentacji danych (po prawej)

Fig. 2. Construction of head-up display (left) and data visualization example (right)

Upraszcza to także znacznie proces nawigacji, ponieważ pilot intuicyjnie kieruje statek powietrzny bezpośrednio na punkt znajdujący się na wskaźniku przeziernym. W przypadku pozycji punktu znajdującego się poza zakresem widoczności wskaźnika przeziernego pilot dostaje informację o kierunku, w jakim powinien nawigować, żeby osiągnąć ten punkt. Rozwiązanie takie ma zastosowanie m.in. podczas nawigacji po trasie przy przekraczaniu punktów zmiany kierunku oraz $\mathrm{w}$ trybach uzbrojenia podczas obliczania punktu zrzutu bomby lub upadku pocisku (tryby CCRP oraz CCIP).

Zintegrowane systemy awioniczne w celu określenia swojego położenia przestrzennego oraz wielu parametrów lotu (prędkości, przyspieszenia) wykorzystują systemy inercjalne oraz odbiorniki GPS. Urządzenia te wypracowują parametry w różnych układach współrzędnych. Prowadzi to do konieczności ciągłego konwertowania tych parametrów pomiędzy układami współrzędnych, które są wykorzystywane w algorytmach obliczeniowych i wizualizacji danych.

\section{Układy współrzędnych w systemach zintegrowanych}

Zintegrowane systemy awioniczne wykorzystują układy współrzędnych związane z Ziemią, poruszającym się obiektem latającym, czy wyposażeniem zamontowanym na pokładzie statku powietrznego. W literaturze spotyka się bardzo bogate nazewnictwo dotyczące tych układów, jak również dowolne kierunki osi współrzędnych, m.in. [1, 7,9]. 
Podstawowymi układami współrzędnych wykorzystywanymi w nawigacji lotniczej są [7]:

- układ współrzędnych geograficznych biegunowych (Latitude Longitude Altitude (LLA) Frame),

- układ współrzędnych inercyjnych (Earth-Centred Inertial (ECI) Coordinate Frame),

- układ współrzędnych prostokątnych (Earth-Centred Earth-Fixed (ECEF) Coordinate Frame),

- geodezyjny układ współrzędnych (Geodetic Coordinate System (GCS));

- nawigacyjny układ współrzędnych (Local Navigation Coordinate Frame),

- układ współrzędnych związany z obiektem (Body Coordinate Frame),

- układy współrzędnych związane z urządzeniami pokładowymi jak: wskaźnik przezierny (HUD), wyrzutnie uzbrojenia podwieszanego (rakiety, bomby, działko).

Układ współrzędnych biegunowych $(\lambda, \varphi, \mathrm{h})$ wykorzystywany jest do opisu położenia obiektu znajdującego się na powierzchni Ziemi lub w niedalekiej odległości od niej (rys. 3). Powszechnie wykorzystywany jest w układach nawigacji satelitarnej (GPS).
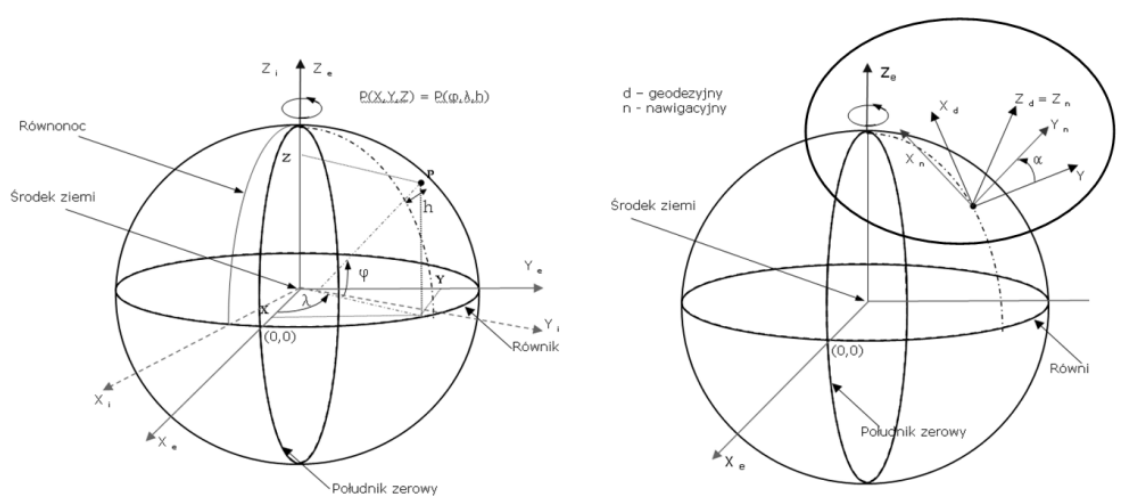

Rys. 3. Układy współrzędnych biegunowych i prostokątnych (po lewej) oraz nawigacyjny i geodezyjny (po prawej)

Fig. 3. Coordinate systems: polar and rectangular (left), navigational and geodetic (right)

Początkiem układu jest środek masy Ziemi. Położenie obiektu w tym układzie współrzędnych wyrażone jest poprzez parametry [7]:

- początek układu współrzędnych (środek masy Ziemi),

- długość geograficzną $(\lambda)$,

- szerokość geograficzną $(\varphi)$,

- wysokość (h).

Układ współrzędnych prostokątnych $\left(\mathrm{X}_{\mathrm{e}}, \mathrm{Y}_{\mathrm{e}}, \mathrm{Z}_{\mathrm{e}}\right)$ jest zdefiniowany (rys. 3) w następujący sposób [7]: 
- początkiem układu współrzędnych jest środek masy Ziemi,

- oś $Z_{\mathrm{e}}$ jest zgodna $\mathrm{z}$ osią obrotu Ziemi, która przechodzi przez jej biegun magnetyczny i jest zgodna $\mathrm{z}$ osią $\mathrm{Z}_{\mathrm{i}}$ układu inercyjnego,

- oś $\mathrm{X}_{\mathrm{e}}$ jest rzutem na płaszczyznę równika dla południka zerowego,

- oś $Y_{e}$ jest wyznaczona na podstawie orientacji osi $Z_{e}$ i $X_{e}$ zgodnie $\mathrm{z}$ zasadą prawej ręki.

Konwersja danych pomiędzy układem współrzędnych biegunowych, a układem prostokątnych określona jest zależnością [7]:

$$
P_{e}=\left[\begin{array}{c}
X_{e} \\
Y_{e} \\
Z_{e}
\end{array}\right]=\left[\begin{array}{c}
\left(N_{e}+h\right) \cos \varphi \cos \lambda \\
\left(N_{e}+h\right) \cos \varphi \sin \lambda \\
\left(N_{e}\left(1-e^{2}\right)+h\right) \sin \varphi
\end{array}\right]
$$

gdzie: $\mathrm{X}_{\mathrm{e}}, \mathrm{Y}_{\mathrm{e}}, \mathrm{Z}_{\mathrm{e}}$ - współrzędne geograficzne w układzie biegunowym,

$\lambda, \varphi$ - długość i szerokość geograficzna,

$\mathrm{N}_{\mathrm{e}}$ - promień Ziemi,

e = 0,08181919 - współczynnik eliptyczności Ziemi,

h - wysokość statku powietrznego nad powierzchnią Ziemi.

Geodezyjny układ współrzędnych $\left(\mathrm{X}_{\mathrm{g}}, \mathrm{Y}_{\mathrm{g}}, \mathrm{Z}_{\mathrm{g}}\right)$ nie jest na stałe (jak poprzednie układy współrzędnych) związany ze środkiem Ziemi (rys. 3), a z poruszającym się w przestrzeni obiektem (np. statkiem powietrznym). Zazwyczaj geodezyjny układ współrzędnych reprezentuje obiekt poruszający się tuż na powierzchnią ziemi i zdefiniowany jest w następujący sposób [7]:

- początkiem układu współrzędnych jest punkt na powierzchni Ziemi, który jest środkiem symetrii poruszającego się obiektu,

- oś $\mathrm{X}_{\mathrm{g}}$ skierowana jest na północ,

- oś $Y_{\mathrm{g}}$ skierowana jest na wschód,

- oś $\mathrm{Z}_{\mathrm{g}}$ wyznaczona jest na podstawie orientacji osi $\mathrm{X}_{\mathrm{g}} \mathrm{i} \mathrm{Y}_{\mathrm{g}}$ zgodnie z zasadą prawej ręki i skierowana jest do góry.

Geodezyjny układ współrzędnych często nosi nazwę układu ENU (EastNord-Up). Można także spotkać odmianę tego układu z osią Z skierowaną w dół. W takim przypadku nosi on nazwę układu NED (Nord-East-Down).

$Z$ kolei nawigacyjny układ współrzędnych $\left(X_{n}, Y_{n}, Z_{n}\right)$ jest zdefiniowany tak jak układ geodezyjny, $\mathrm{z}$ tą różnicą że jego osie $\mathrm{X}_{\mathrm{n}}, \mathrm{Y}_{\mathrm{n}}$ są przesunięte o kąt „wędrujący” $\alpha$ wokół osi $Z$ względem osi $\mathrm{X}_{\mathrm{g}}, \mathrm{Y}_{\mathrm{g}}$ układu geodezyjnego (rys. 3) i zdefiniowany jest w następujący sposób [7]:

- początkiem układu współrzędnych jest punkt na powierzchni Ziemi, który jest środkiem symetrii poruszającego się obiektu,

- oś $\mathrm{X}_{\mathrm{n}}$ skierowana jest na północ i przesunięta jest o kat $\alpha$ względem osi $X_{g}$, 
- oś $\mathrm{Y}_{\mathrm{n}}$ skierowana jest na wschód i przesunięta jest o kąt $\alpha$ względem osi $Y_{g}$,

- oś $Z_{\mathrm{n}}$ wyznaczona jest na podstawie orientacji osi $\mathrm{X}_{\mathrm{g}} \mathrm{i} \mathrm{Y}_{\mathrm{g}}$ zgodnie z zasadą prawej ręki i skierowana jest do góry.

Układ współrzędnych obiektu (samolotu) jest układem stałym względem poruszającego się w przestrzeni obiektu (rys. 4) i jest zdefiniowany w następujący sposób [7]:

- początek układu współrzędnych jest umieszczony w środku masy poruszającego się obiektu,

- oś $\mathrm{X}_{\mathrm{b}}$ jest zgodna $\mathrm{z}$ osią podłużną, kierunek dodatni jest zgodny $\mathrm{z}$ kierunkiem ruchu obiektu,

- oś $\mathrm{Y}_{\mathrm{b}}$ jest osią prostopadłą do osi $\mathrm{X}_{\mathrm{b}} \mathrm{o}$ kierunku dodatnim skierowanym w prawo w stosunku do kierunku osi $\mathrm{X}_{\mathrm{b}}$,

- oś $\mathrm{Z}_{\mathrm{b}}$ jest osią prostopadłą do płaszczyzny $\mathrm{X}_{\mathrm{b}}, \mathrm{Y}_{\mathrm{b}}$ o kierunku dodatnim skierowanym w dół.

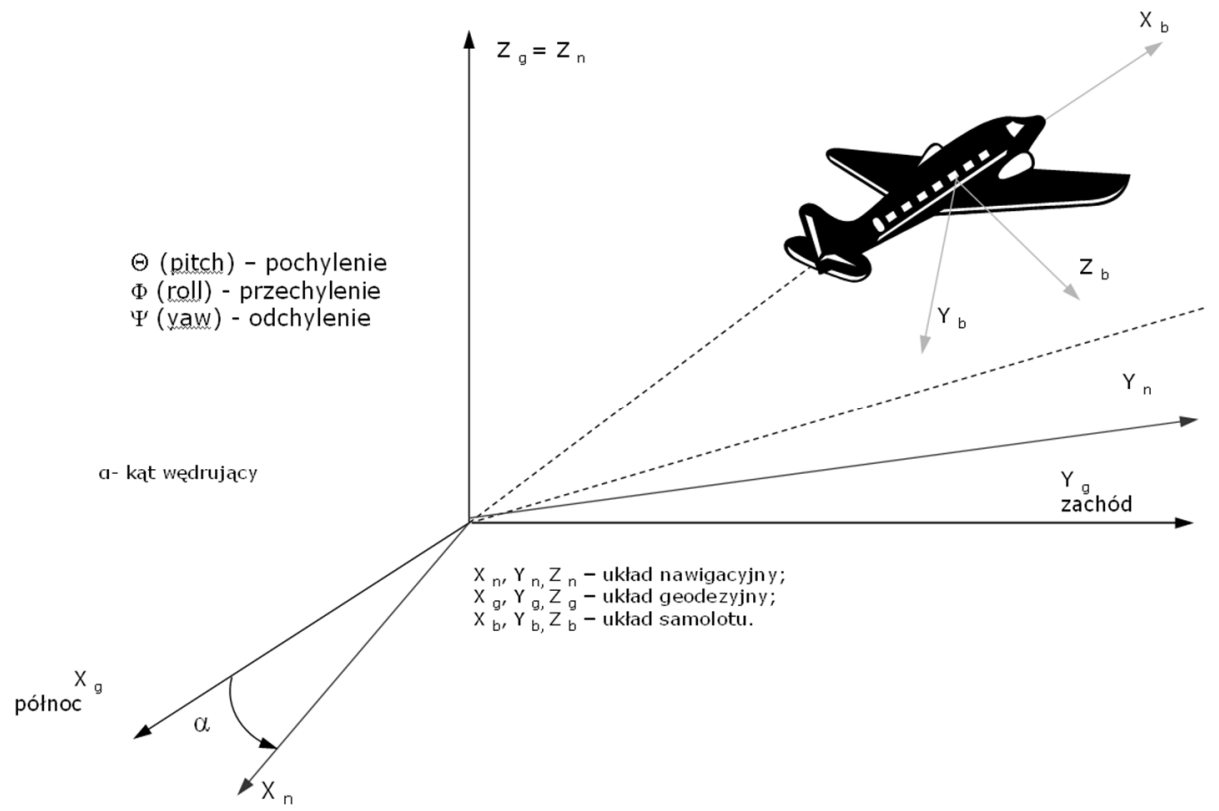

Rys. 4. Układ współrzędnych związanych ze statkiem powietrznym jako obiektem latającym

Fig. 4. Coordinate system connected with aircraft as a flying object

Konwersja danych pomiędzy układem współrzędnych geodezyjnym, a układem współrzędnych obiektu określona jest zależnością [7]: 
$\left[\begin{array}{c}X_{b} \\ Y_{b} \\ Z_{b}\end{array}\right]=\left[\begin{array}{ccc}\cos \Theta \cos \Psi & \sin \Theta \sin \Phi \cos \Psi-\cos \Phi \sin \Psi & \sin \Theta \cos \Phi \cos \Psi+\sin \Phi \sin \Psi \\ \cos \Theta \sin \Psi & \sin \Theta \sin \Phi \sin \Psi+\cos \Phi \cos \Psi & \sin \Theta \cos \Phi \sin \Psi-\sin \Phi \cos \Psi \\ -\sin \Theta & \cos \Theta \sin \Phi & \cos \Theta \cos \Phi\end{array}\right]\left[\begin{array}{l}X_{n} \\ Y_{n} \\ Z_{n}\end{array}\right]$

Przykładowy algorytm konwersji punktu znajdującego się w przestrzeni do jego wyświetlenia na wskaźniku przeziernym HUD przedstawiono na rysunku 5.

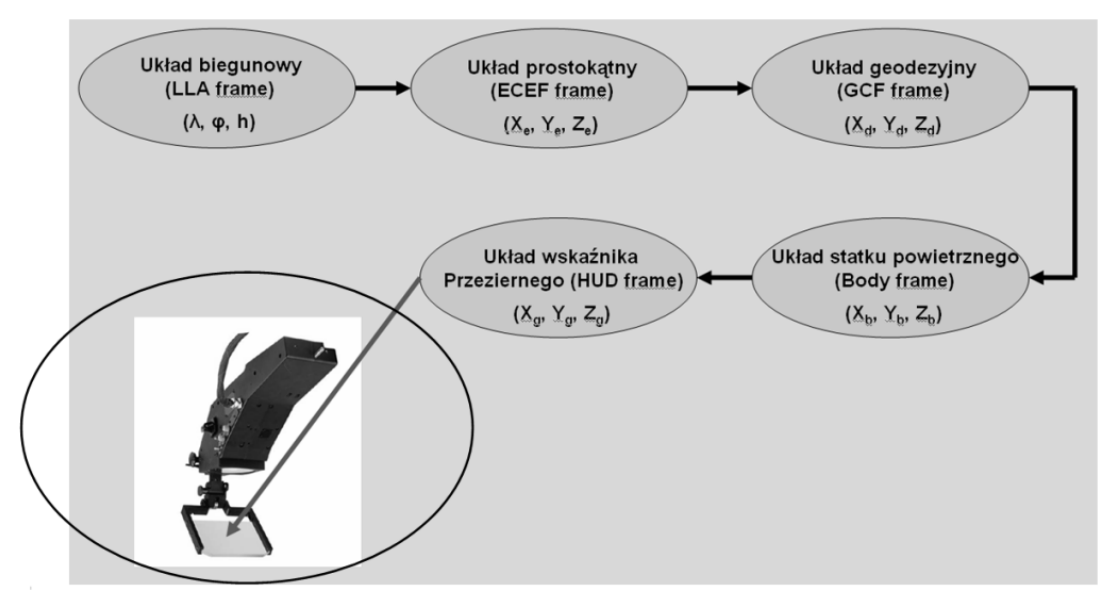

Rys. 5. Algorytm konwersji punktu w przestrzeni do układu współrzędnych wskaźnika HUD

Fig. 5. Algorithm to convert the point in space to coordinate system of HUD

Algorytm ten składa się z wielu przeliczeń pomiędzy układami współrzędnych, z których ostatnim etapem jest przeliczenie do układu współrzędnych wskaźnika przeziernego HUD. W efekcie wyświetlenie symbolu punktu na wskaźniku pokrywa się z jego rzeczywistym położeniem przestrzennym.

\section{Weryfikacja konwersji danych w systemach zintegrowanych}

Praktyczną weryfikację algorytmów konwersji współrzędnych przedstawiono na przykładzie wyliczania punktu zrzutu bomby i upadku pocisku w trybach uzbrojenia CCRP i CCIP, wykorzystywanych w algorytmach balistycznych opracowanych na potrzeby śmigłowca W-3PL Głuszec [8].

Tryb CCRP (Continuous Computation of Release Point) charakteryzuje ciągłe obliczanie punktu zrzutu (rys. 6) i jest stosowany podczas użycia zasobników z bombami małogabarytowymi oraz zasobników z minami narzutowymi. Zadanie pilota polega na zaznaczeniu początku i końca celu, wykonaniu lotu na cel oraz utrzymywaniu przycisku bojowego w położeniu naciśniętym. Sygnał zrzutu bomb/min następuje automatycznie po spełnieniu warunku równości donośności bomb/min i odległości bieżącej do początku celu. Praktyczny sposób 
zobrazowania przykładowego strzelania w trybie CCRP wraz $\mathrm{z}$ widokiem jego wyników z głowicy obserwacyjnej TOPLITE (rys. 7).

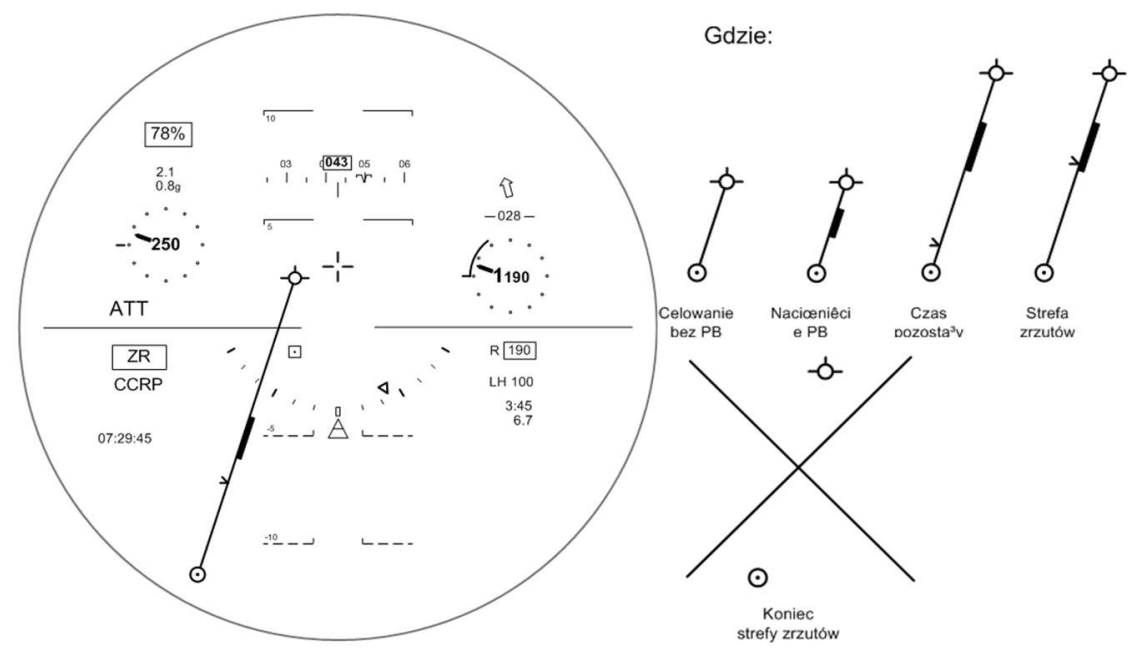

Rys. 6. Zobrazowanie na wskaźniku przeziernym dla zrzutu bomby w trybie CCRP

Fig. 6. Visualisation on the head-up display for dump bombs in CCRP mode
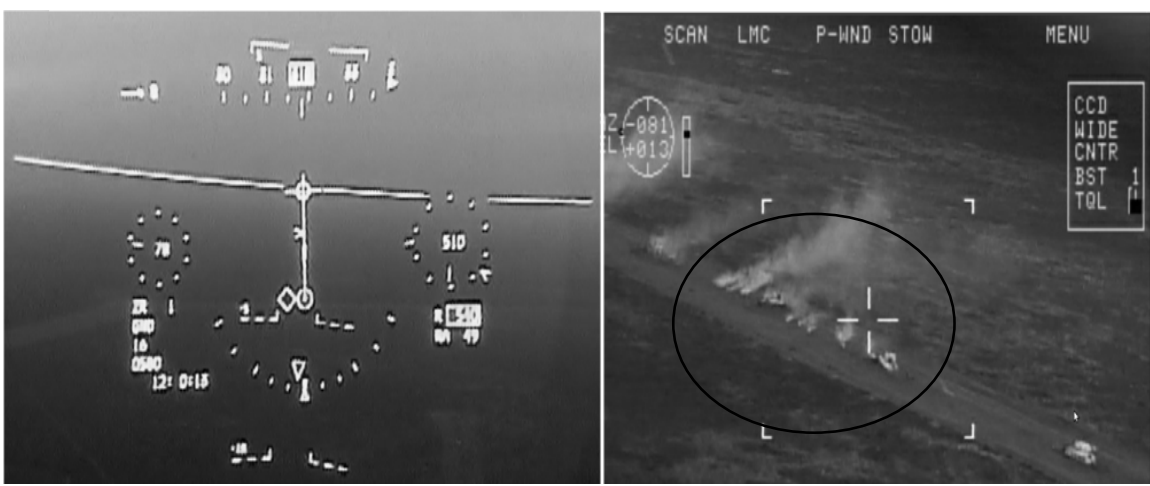

Rys. 7. Tryb CCRP na wskaźniku HUD (po lewej) i widok z głowicy TOPLITE (po prawej)

Fig. 7. CCRP mode on the HUD (left) and the view from TOPLITE head (right)

Tryb CCIP (Continuous Computation of Impact Point) charakteryzuje ciągłe obliczanie punktu upadku (rys. 8) i jest stosowany podczas użycia niekierowanych pocisków rakietowych oraz broni lufowej do celów naziemnych i powietrznych. Polega on na ciągłym wyliczaniu współrzędnych punktu upadku pocisku. Zadanie pilota polega na dokonaniu wyboru środka bojowego, pokryciu z celem i naciśnięciu przycisku bojowego. Odpalenie (wystrzelenie) pocisku następuje z chwilą naciśnięcia przycisku bojowego. 


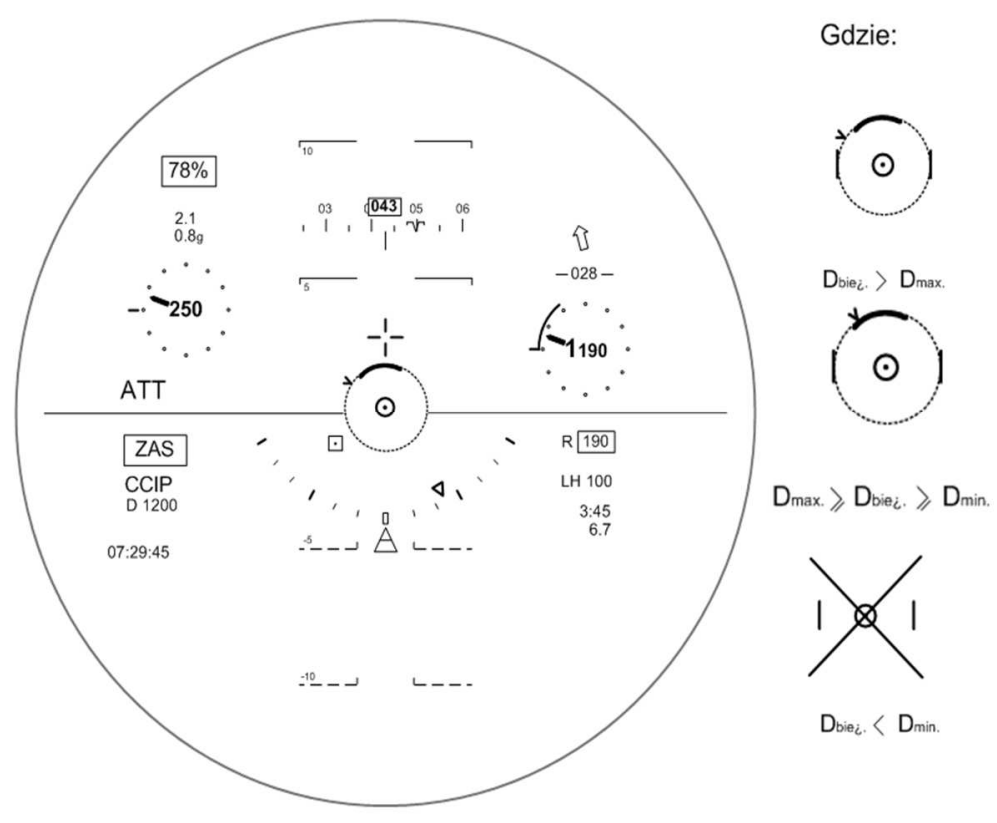

Rys. 8. Zobrazowanie na wskaźniku przeziernym HUD dla zrzutu bomby w trybie CCIP

Fig. 8. Visualisation on the head-up display HUD for dump bombs in CCIP mode

\section{Podsumowanie}

Zintegrowane systemy awioniczne stanowią obecnie standardowe wyposażenie współczesnych statków powietrznych, zwiększające ich możliwości bojowe i bezpieczeństwo lotu. W polskim lotnictwie wojskowym statkiem powietrznym posiadającym zintegrowany cyfrowo system awioniczny jest samolot wielozadaniowy F-16 (wprowadzony do eksploatacji w latach 2006-2008). Posiada on rozbudowane cyfrowe magistrale wymiany danych, oparte na standardzie MIL-1553B. Informacja pilotażowo-nawigacyjna i obserwacyjno-celownicza obrazowana na wskaźniku przeziernym HUD i monitorach wielofunkcyjnych MFD jest konwertowana w komputerze misji MMC. Dodatkowym odbiornikiem danych jest nahełmowy system celowniczy JHMCS.

Ponadto, zintegrowane systemy awioniczne jako nowe wyposażenie zostały opracowane i zabudowane na pokładach modernizowanych statków powietrznych m.in. samolotów MiG-29 (integracja wykonana przez Wojskowe Zakłady Lotnicze WZL-2 w latach 2008-2010) oraz śmigłowców W-3PL Głuszec i samolotu PZL-130 Orlik MPT (integracja wykonana przez Instytut Techniczny Wojsk Lotniczych w latach 2004-2008 i 2012-2015). Dla przykładu, w systemie awionicznym śmigłowca W-3PL Głuszec, zintegrowanym przez Instytut Techniczny Wojsk Lotniczych, przetwarzanie danych pilotażowo-nawigacyjnych i celowniczych stosowane jest podczas realizacji misji obserwacyjnych (przy 
użyciu głowicy obserwacyjno-celowniczej TOPLITE) oraz podczas wykorzystania systemu uzbrojenia współpracującego z nahełmowym systemem celowniczym NSC-1 Orion (w wersji proponowanej do zabudowy).

Jednym z głównych problemów technicznych występujących w procesie integracji urządzeń awionicznych, realizowanej przez Instytut Techniczny Wojsk Lotniczych, było opracowanie efektywnego sposobu przetwarzania informacji pilotażowo-nawigacyjnej i obserwacyjno-celowniczej, bazującego na danych otrzymywanych z magistrali cyfrowych MIL-1553B i ARINC-429. Wśród urządzeń pozyskujących i dystrybuujących informację pilotażowo-nawigacyjną znajdują się między innymi centrala nawigacji inercjalnej INS/GPS EGI-3000 oraz centrala danych aerodynamicznych ADU-3200.

Zastosowane metody konwersji danych nawigacyjnych wykorzystywanych w zintegrowanym systemie awionicznym śmigłowca W-3PL Głuszec umożliwiły realizację wyznaczania współrzędnych punktu upadku pocisku w trybie CCIP oraz punktu zrzutu bomb/min w trybie CCRP. Do wyliczeń współrzędnych punktu odpalenia pocisków niekierowanych: S-5 kal. $57 \mathrm{~mm}$ (wyrzutnie MARS-2), S-7 kal. $70 \mathrm{~mm}$ (wyrzutnie M-260) i S-8 kal. $80 \mathrm{~mm}$ (wyrzutnie B-8-10) zastosowano konwersję danych o bieżącym położeniu kątowym śmigłowca, natomiast do wyznaczenia czasu dolotu do obszaru zrzutu bomb lub min narzutowych z podwieszanych zasobników ZR-8 i PLATAN wykorzystano konwersję danych o bieżącej pozycji nawigacyjnej śmigłowca.

\section{Literatura}

[1] Bao-Yen Tsui J.: Fundamentals of Global Positioning Systems Receivers: A Software Approach, John Wiley \& Sons, London 2000.

[2] Cai G.: Unmanned Rotorcraft Systems, Advances in Industrial Control, SpringerVerlang, London 2011.

[3] Cieślik A.: Rodzaje integracji i standardy transmisji danych zintegrowanych systemów awionicznych, VI Konferencja Awioniki „AWIONIKA 2010”, Bezmiechowa 2010.

[4] Dokument standaryzacyjny: MIL-STD-1553B Tutorial, Condor Engineering, 2005.

[5] Materiały techniczne firmy Sextant Avionique: „Bezwładnościowy system nawigacyjny TOTEM 3000. IRYDA-M-96. Functional Specification”, Bordeaux 1997.

[6] Moir I., Seabridge A.: Military avionics system, John Wiley \& Sons, London 2006.

[7] Noureldin A.: Fundamentals of Inertial Navigation, Satellite-based Positioning and their Integration, Springer-Verlag, Berlin Heidelberg 2013.

[8] Pietraszek M.: Eksperymentalna weryfikacja matematycznego modelu systemu celowniczego śmigłowca, Instytut Techniczny Wojsk Lotniczych, Warszawa 2009.

[9] Polska Norma PN-ISO: Dynamika lotu, Pojęcia, wielkości i symbole, Część 1, Ruch statku powietrznego względem powietrza, PKN, Warszawa 2004. 


\section{METHODS OF NAVIGATION DATA CONVERSION IN REFERENCE SYSTEMS USED IN INTEGRATED AVIONIC SYSTEMS}

\section{S u m m a r y}

This paper presents selected results of the analytical work carried out in the Air Force Institute of Technology within the capabilities of a computer navigation data conversion in reference systems used in integrated avionics systems. On example of built avionics system for the helicopter W-3PL Capercaillie possibilities of computer processing of pilot-navigation and aiming data in combat applications, during execution of the observation mission (using the observation and surveillance system TOPLITE) and the use of the weapon system with helmet-mounted cueing system NSC-1 Orion were presented. In order to illustrate pilot-navigation and observation-aiming information processing operations carried out in it, used methods for converting data in navigation modes CCIP and CCRP were discussed.

Keywords: avionics navigation systems, data conversion

DOI: $10.7862 / \mathrm{rm} .2017 .02$

Otrzymano/received: 1.12 .2016

Zaakceptowano/accepted: 4.03.2017 